https://doi.org/10.18485/iipe_regbezb.2021.ch1

\title{
STANJE I DOMETI TEORIJE REGIONALNOG BEZBEDNOSNOG KOMPLEKSA U PROUČAVANJU REGIONA U MEĐUNARODNIM ODNOSIMA
}

\author{
Marko KOVAČEVIĆ ${ }^{1}$ \\ Andrej CVETIĆ ${ }^{2}$
}

Apstrakt: U ovom radu obrazložićemo stav da je teorija regionalnog bezbednosnog kompleksa (TRBK) (Buzan and Waever 2003), najadekvatnije pozicionirana među različitim "regionalističkim" pristupima u međunarodnim odnosima, bilo $\mathrm{u}$ pogledu izgradnje teorije bilo $\mathrm{u}$ empirijskim istraživanjima o regionalnoj bezbednosti. Ciljevi ovog rada su trostruki: a) da predstavi TRBK u savremenom proučavanju regionalne bezbednosti; b) da mapira studije regionalne bezbednosti i sagleda odnos TRBK sa drugim (srodnim/rivalskim) teorijama; c) da oceni karakter sagledanog odnosa TRBK i drugih teorija regionalne bezbednosti. Tako postavljenim ciljevima odgovaraju tri metodološka koraka. Prvo, pregledom literature želimo ukazati na teorijsku evoluciju i empirijsku primenu TRBK tokom prethodne dve decenije. Drugo, ponudićemo pregled i klasifikaciju relevantnih koncepata drugih ",regionalističkih" teorija za koje smatramo da "rezonuju“ sa okvirom TRBK. Treće, odgovorićemo na pitanje da li je i u kojoj meri je TRBK kompatibilna sa konceptima užih, rivalskih pristupa. Smatramo da TRBK može poslužiti kao svojevrstan „interfejs“ širih studija

\footnotetext{
${ }^{1}$ Fakultet političkih nauka, Univerzitet u Beogradu, Beograd.

E-mail: marko.kovacevic@fpn.bg.ac.rs.

${ }^{2}$ Fakultet političkih nauka, Univerzitet u Beogradu, Beograd.

E-mail: cvetic.andrej@gmail.com.

Rad autora na ovom tekstu deo je aktivnosti u okviru projekta „Politički identitet Srbije u regionalnom i globalnom kontekstu“ (br. 179076), koji finansira Ministarstvo prosvete, nauke i tehnološkog razvoja Republike Srbije.
} 
regionalne bezbednosti. Kako bismo ilustrovali predloženi postupak, u trećem odeljku rada se raspravlja o prednostima koje TRBK kao teorija srednjeg obima ima u odnosu na rivalske pristupe koji se usredsređuju na regionalne poretke (Katzenstein 2005; Frazier and Stewart-Ingersoll 2010), regionalne bezbednosne zajednice (Adler and Barnett 1998), ili regionalni "multipleks" međunarodni poredak (Acharya 2014; Acharya 2018). Zaključak upućuje na mogućnosti hibridizacije TRBK i srodnih/rivalskih teorijskih pristupa, što otvara značajna pitanja za dalji razvoj istraživačkog programa studija regionalne bezbednosti u trećoj deceniji XXI veka.

Ključne reči: međunarodni odnosi, regionalizam, regionalna bezbednost, teorija regionalnog bezbednosnog kompleksa (TRBK), regionalni bezbednosni poredak, bezbednosna zajednica, geopolitika, multipolarizacija.

\section{UVOD}

Savremene studije bezbednosti razvijaju se na osnovama koje odstupaju od tradicionalnog državocentričnog shvatanja bezbednosti, mahom vezanog za politiku velikih sila. Iako velike sile presudno utiču na bezbednosnu dinamiku na globalnom nivou, promena $u$ rasporedu moći u okviru međunarodnog sistema nakon Hladnog rata učinila je da globalni ili sistemski nivo analize $u$ međunarodnim odnosima sve manje može da objasni nastajuću bezbednosnu dinamiku u regionima. Uprkos početnom periodu posthladnoratovskog "unipolarnog momenta“, kada su SAD apsolutno dominirale na globalnom nivou, u periodu nakon 2008. godine, rastuće regionalne sile, pre svega one iz redova BRICS, nastoje da učvrste svoj položaj u središtu bezbednosnih kompleksa. Neke od njih, poput Kine, imaju i globalne ambicije, što pokazuju i geo-ekonomskim projektima poput inicijative Pojas i put (engl. The Belt and Road Initiative).

Iako se u poslednjih petnaestak godina sve više ističu države izazivači moći Sjedinjenih Američkih Država, a pre svega Kina, raspoloživi kapaciteti i vojno prisustvo dozvoljavaju jedino Sjedinjenim Američkim Državama da čitav svet posmatraju kao nivo na kojem se ostvaruje njihova spoljna politika i nacionalna bezbednost. Ostale srednje sile uglavnom svoje spoljnopolitičke i bezbednosne interese ostvaruju na regionalnom i međuregionalnom nivou, dok male države svoje politike vode unutar regiona oslanjajući se pretežno na multilateralizam. Materijalni i nematerijalni kapaciteti, kao merljivi parametri, zajedno sa njihovim interesima čine da većina država svoje bezbednosne i političke interese ipak ostvaruju na nižem, regionalnom 
nivou (Thompson 1973). Za većinu država, bezbednosne interakcije i primarne pretnje bezbednosti i dalje su uže geografski uslovljene i potiču iz neposrednog susedstva tj. regiona, što ukazuje na realpolitički, koliko i teorijski značaj regiona.

O značaju regiona kao analitičkog koncepta pišu mnogi autori (Vayrynen 1984; Vayrynen 2003; Lake and Morgan 1997; Ayoob 1999; Hettne and Soderbaum 2000). Preovladava shvatanje da region kao teritorija i/ili akvatorija srednje veličine predstavlja podesan okvir za posmatranje odnosa između država (Ejdus 2017, 236). Regioni su u literaturi predmet interesovanja postali tokom sedamdesetih i osamdesetih godina $X X$ veka, kada Vilijam Tompson (William Thompson) (1973) piše o regionalnim podsistemima, a Raimo Vajrinen (Raimo Vayrynen) (1984) o regionalnim konfliktnim formacijama. U studijama bezbednosti, interesovanje za region kao jedinstven nivo analize učvrstio je Beri Buzan (Barry Buzan) u knjizi People, States and Fear iz 1983. godine, ${ }^{3}$ razvijajući teoriju regionalnog bezbednosnog kompleksa $\mathrm{u}$ domenu političkih i vojnih sektora. Interesovanje za regione poraslo je sredinom devedesetih godina kada Dejvid Lejk (David Lake) i Patrik Morgan (Patrick Morgan) (1997) pišu o regionalnim bezbednosnim porecima (engl. regional security orders), odnosno, kada Emanuel Adler (Emanuel Adler) i Majkl Barnet (Michael Barnet) (1998) afirmišu koncept bezbednosne zajednice (engl. security community) $\mathrm{u}$ regionalnom kontekstu. Istovremeno, Mohamed Ajub (Mohammed Ayoob) (1999) proučava razvoj regionalnih sistema i regionalnih društava (engl. regional societies). Ovakva teorijska kretanja tokom devedesetih godina XX veka u skladu su sa interesovanjem za „novim regionalizmom" u okviru međunarodne političke ekonomije. ${ }^{4}$

$\mathrm{U}$ raspravama koje vode proučavaoci međunarodnih odnosa tokom prve dve decenije XXI veka, mogu se čuti mišljenja da se danas, u najmanju

\footnotetext{
3 „,Dosta je napora uloženo u analizu bezbednosti na državnom nivou, kako u analizu politike nacionalne bezbednosti, tako i u analizu kriznih žarišta. Slično tome, mnoge analize orijentisane su prema velikim apstrakcijama sistemske analize. Međutim, između njih pronalazimo samo maglovite i izvedene pojmove regionalne ravnoteže snaga i podsistema. Međutim, upravo u ovoj srednjoj oblasti, koncept bezbednosti ima jednu od svojih najkorisnijih primena“ (Buzan 1983, 105 navedeno prema Ejdus 2012, 253).

${ }^{4} \mathrm{O}$ starom i novom regionalizmu videti: Vayrynen 2003. Takođe, u članku iz 2005. godine, Bjorn Hetne (Bjorn Hettne) ukazuje na teškoće u definisanju i različitim shvatanjima "regionalizma“, te da je preterano govoriti o novom i starom regionalizmu. On zaključuje da regionalizam i regionalni faktori mogu da utiču na oblikovanje svetskog poretka.
} 
ruku, živi u "svetu regiona“ (Katzenstein 2005), da postoji „regionalna arhitektura međunarodne politike u nastajanju" (Acharya 2007), i „Višeregionalni sistem međunarodnih odnosa“" (Hurrell 2007; Nolte 2010). Činjenica da je region, usled svog empirijskog značaja, postao predmet trajnijeg interesovanja $u$ međunarodnim odnosima, stvorila je potrebu za razmatranjem pozicije regionalnog nivoa analize, tj. njegove utemeljenosti i upotrebljivosti u studijama bezbednosti.

U ovom članku bavićemo se analizom teorije regionalnih bezbednosnih kompleksa (TRBK), smeštajući je u kontekst proučavanja regiona $\mathrm{u}$ studijama bezbednosti. Želimo ukazati na to da, u odnosu na istorijski razvoj regionalističkih pristupa, TRBK predstavlja svojevrsnu prekretnicu jer je uspela da na istraživački plodan način spoji realističko i konstruktivističko proučavanje regiona. Takođe, ova teorija, za razliku od prethodećih pristupa, pokazuje dovoljno otvorenosti da sa njom komuniciraju rivalski pristupi i da se na njenoj osnovi grade sintetički pristupi regionima $u$ studijama bezbednosti. Stoga je naša namera da ukažemo u kojoj meri TRBK rezonuje sa savremenim tokovima u studijama bezbednosti, kroz analizu kompatibilnosti njihovih konceptualnih aparata. Ostatak odeljaka ovog teksta organizovan je $\mathrm{u}$ vidu pregleda pristupa koncipiranju regiona $\mathrm{u}$ međunarodnoj bezbednosti, kao i konceptualne analize TRBK, praćenu pregledom i analizom onoga što vidimo kao tri najznačajnije struje regionalističkih pristupa: regionalnih poredaka (Katzenstein 2005; Frazier and Stewart-Ingersoll 2010), regionalnih bezbednosnih zajednica (Adler and Barnett 1998), i regionalnih "multipleks“ međunarodnih poredaka (Acharya 2014; Acharya 2018).

\section{REGION U MEĐUNARODNIM ODNOSIMA: SAMO JOŠ JEDAN PROBLEM?}

Regioni su dugo bili relativno zanemareni $\mathrm{u}$ proučavanju međunarodnih odnosa i studijama bezbednosti. Osim sporadičnog interesovanja istraživača za proučavanje "regionalnih podsistema“ (Thompson 1973), nakon završetka Hladnog rata dolazi do preokreta i afirmacije regiona kao relativno samostalne jedinice ili nivoa analize. $O$ tome svedoči živa aktivnost u okviru regionalističkog pristupa tj. studija (novog) regionalizma. Regionalizam je uglavnom predstavljao perspektivu sagledavanja sveta sastavljenog od fiksiranih geografskih regiona, dok sa 
pojavom socijalnog konstruktivizma u međunarodnim odnosima tokom 1990-ih i početkom 2000-ih godina, sve više maha uzima shvatanje regiona kao društvene konstrukcije zavisne od konteksta (Neumann 1994; Nojman 2011). Premda je geografija osnova svakog regiona, on se menja i svoja značenja dalje dobija u kulturnom, političkom, ekonomskom (Vayrynen 2003) pa i bezbednosnom smislu (Buzan 1991; Buzan et al. 1998).

Regionalna bezbednost je postala predmet posebnih istraživanja, a regionalni nivo analize njen neodvojivi deo. Tako, na primer, Lejk i Morgan (Lake and Morgan) (1997) smatraju da na regionalnom nivou treba istraživati dinamiku sukoba i saradnje, i da je taj nivo važniji nego ranije. Piter Kacenstajn (Peter Katzenstein) (2005) ide dotle da početkom XXI veka iznosi ocenu o "regionalnoj politici“, kao zameni za međunarodnu politiku, a u kojoj SAD imaju vodeću ulogu. Nasuprot tome, Amitav Ačarija (Amitav Acharya) (2014), podvlačeći značaj nezapadnih međunarodnih odnosa, smatra da je došlo do „kraja američkog poretka“ te da je stvarnost, ali i trend razvoja svetske politike „multipleks“ međunarodni poredak sa višestrukim lojalnostima država na temelju regionalne difuzije moći.

U okvirima proučavanja regiona u studijama bezbednosti, racionalistički i konstruktivistički pravci se izdvajaju kao osnovni u definisanju i njihovoj izgradnji. Racionalistički pristup obuhvata sve one konceptualizacije koje su $u$ vezi sa realističkim i liberalnim teorijama, tj. geopolitičkim i funkcionalističkim/institucionalističkim shvatanjima međunarodnih odnosa. Tako teoretičar regionalizma, Vajrinen (2003), razlikuje fizičke od funkcionalnih regiona. Fizički regioni su geografski u pogledu objektivnih karakteristika koje određuju međunarodne odnose, te stoga mogu biti smatrani i geopolitičkim (Vayrynen 2003). Drugačiji od ovog realističkog shvatanja jesu funkcionalni regioni, koji se mogu smatrati ekonomskim, ekološkim ili kulturnim celinama. Sa druge strane, prema poststrukturalisti Iveru Nojmanu (Iver B.Neumann) (1994), postoje tri pristupa definisanju regiona: "unutar-izvan“ (engl. inside-out) koji se zasniva na kulturnoj integraciji, „,izvan-unutra“ (engl. outside-in) koji se zasniva na geopolitici, i „izgradnja regiona“ (engl. region-building) kao diskurzivna tvorevina koja postavlja pitanje „čiji region“. Region, pored svoje materijalne stvarnosti, istovremeno može biti i proizvod društvenog konstruisanja. Značenja i koncepcije nekog regiona određene su pre svega raspodelom moći i ideja njegovih političkih „,neimara“ kao proizvođača diskursa (Nojman, 2011).

Oba pravca definisanja regiona tvrde da ovaj nivo analize može zahvatiti glavninu međudržavnih interakcija te se, pored unutarregionalne, može 
uočiti i međuregionalna dinamika. Razlog tome je što samo velike sile mogu konstantno učestvovati u prekoregionalnoj bezbednosnoj dinamici i bivaju opažene kao nadregionalni akteri. ${ }^{5}$ Region time dobija analitičku utemeljenost i samostalnost $\mathrm{u}$ odnosu na ranije dominantan sistemski ili globalni nivo analize. Takođe, region se pokazuje kao analitički efikasnije oruđe u odnosu na samu državu kao jedinicu analize jer daje neposredan kontekst $\mathrm{u}$ kom se formiraju pretnje i rizici na koje država mora da odgovori. Jedan od razloga gubljenja značaja globalnog u odnosu na regionalno je, prema Buzanu i saradnicima (Buzan et al.) (1998), i činjenica da je prestankom bipolarnog nadmetanja prestala i potreba da se sile odmeravaju na globalnom nivou.

\section{TEORIJA REGIONALNIH BEZBEDNOSNIH KOMPLEKSA: PUT KA POTPUNIJEM SHVATANJU REGIONA?}

U knjizi People, States and Fear (1991, drugo izdanje), Beri Buzan u studije bezbednosti uvodi regionalni nivo analize kao podsistemski, iako je, kako to primećuje Ejdus $(2017,238)$, Ronald Jalem (Ronald Yalem) još ranije spominjao da se taj nivo analize može dodati Volcovom (Kenneth Waltz) sistemu međunarodne politike. Pristup Buzana i saradnika u okviru Kopenhaške škole, uvažavajući savremenu zamisao bezbednosti (proširenu i produbljenu), predstavlja presek globalističkog, neorealističkog i konstruktivističkog pogleda na međunarodnu bezbednost, gde se neorealističko insistiranje na ulozi države usklađuje sa konstruktivističkom ontologijom koja omogućava upotrebu teorije sekuritizacije i bezbednosnih sektora u analizi (Buzan and Waever 2003). Buzanov teorijski okvir, koji on razvija u kasnijim radovima, možemo okarakterisati kao uključujući budući da se zasniva na teorijskim pretpostavkama strukturalne teorije međunarodnih odnosa, istovremeno raskidajući sa državocentričnim pristupom međunarodnoj politici. ${ }^{6} \mathrm{U}$ suštini, od strukturalnih elemenata Buzan i dalje uzima državu kao primarnu, središnju jedinicu, koja kao subjekat bezbednosti oblikuje bezbednosnu dinamiku - ali na regionalnom

\footnotetext{
${ }^{5} \mathrm{Npr}$. regionalne sile poput Indije mogu da povremeno projektuju sopstvenu moć na prekoregionalnom planu.

${ }^{6}$ Buzan sa saradnicima kasnije, na drugom mestu, pominje da postoji pet nivoa analize: međunarodni sistem, međunarodni podsistem, jedinice, podjedinice i pojedinci (Buzan et al. 1998, 5; vidi i: Buzan et al. 1993).
} 
nivou. ${ }^{7}$ Prema njegovom i Vejverovom shvatanju, pretnje se brže i lakše prenose preko kraćih razdaljina, te je bezbednost $\mathrm{i}$ dalje primarno prostorne i teritorijalne prirode (Buzan and Waever 2003). Jedna od ograda ove unapređene verzije TRBK jeste da su promena u globalizovanim svetskim odnosima i tehnološka revolucija u oružanim snagama činioci koji mogu bezbednost učiniti dominantno globalnim i donekle deteritorijalizovanim fenomenom, čime bi regionalni obziri u takvoj situaciji eventualno izgubili na svom analitičkom značaju. ${ }^{8}$ Bezbednost bi i dalje bila nacionalna, ali bi se dominantno očitavala na globalnom nivou. Zamislimo hipotetičku situaciju kada bi sve države raspolagale modernim naoružanjem i interkontinentalnim raketama sa nuklearnim bojevima glavama - tada geografska udaljenost ne bi bila odvraćajući činilac koji bi onemogućavao takvu nekonvencionalnu oružanu pretnju. ${ }^{9}$

Buzan i Vejver (2003) nivoe ne posmatraju kao nekakve samostalne teorije, već kao način da se složene pojave raščlane i smeste u nekakav prostorni okvir za teoretisanje. Oni time aludiraju na Dejvida Singera (David Singer) i kao primer navode neorealizam koji „,smešta objašnjenje (strukturu) na sistemski nivo, a svoj glavni ishod (samopomoć) na nivo jedinice" (Singer 1961; Onuf 1995; Ejdus 2017). Na drugom mestu, Buzan i saradnici o nivoima analize pišu kao o „predmetima analize koji su određeni nizom prostornih skala, od malog prema velikom“ $(1998,5)$. Taj međuodnos različitih nivoa analize i celina bezbednosne dinamike, koja se može uočiti preko više nivoa analize, rečnikom TRBK naziva se bezbednosna konstelacija, i prema Buzanu i Vejveru „da bi se mogao naslikati pravi

\footnotetext{
${ }^{7}$ Vejver piše o tome da se koncept bezbednosti odnosi na državu i da postoje tri nivoa analize. „[...] pojedinac, država i međunarodni sistem - bili su središnji za Buzanovu argumentaciju, iako je nacionalna bezbednost ostala, na neki način, povlašćena [...] Buzan smatra da je državni nivo privilegovan čak iako nacionalna bezbednost ne može biti shvaćena samo na državnom nivou. Ono što povezuje nacionalnu bezbednost sa drugim nivoima nije prvenstveno bezbednost pojedinca i međunarodna bezbednost, već dinamika i politički procesi raznih vrsta na tim drugim nivoima..." „, $[.$.$] Nacionalna bezbednost u osnovi zavisi$ od međunarodne dinamike (posebno regionalne), ali to nije isto kao i odnos između nacionalne i međunarodne bezbednosti“ (Weaver 2007, 66-98, 68, 69).

${ }^{8}$ Uporediti sa razmatranjem globalizacije i deteritorijalizacije bezbednosti, gde se najviše sekuritizuju globalizacija, globalno zagrevanje, transnacionalni organizovani kriminal i međunarodni terorizam (Buzan and Waever 2003, 464-468).

${ }^{9} \mathrm{Npr}$. o ulozi geografskih prepreka u međunarodnim odnosima uputno je pogledati ideju o „zaustavljajućoj moći mora“ kod Džona Miršajmera (John Mearsheimer) (2009).
} 
portret međunarodne bezbednosti, treba razumeti oba nivoa [regionalni i globalni] odvojeno, kao i interakciju koja postoji među njima“" $(2003,4)$.

Dok se bezbednost može ogledati kao odnos između država, Kopenhaška škola je u skladu sa proširenim shvatanjem ovog koncepta iznedrila sektorsku analizu. ${ }^{10}$ Naime, bezbednost se posmatra u pet sektora: politički, vojni, ekonomski, ekološki i socijetalni. Svaki od sektora ima karakteristični referentni objekat bezbednosti. Tako se u vojnom i političkom sektoru, pre svega, kao referentni objekat uzimaju države, političke elite i pojedinci. Ekonomski sektor podrazumeva nacionalni ili globalni ekonomski poredak. Ekološki sektor kao referentni objekat vidi ekosferu (kao uslov za razvoj civilizacije). Socijetalna bezbednost se odnosi na osiguravanje kolektivnog identiteta neke društvene grupe (npr. politički, verski ili kulturni identitet). ${ }^{11}$ Primećujemo da se $\mathrm{u}$ analizi, uglavnom, posmatraju politički ili vojni sektori koji u najvećoj meri određuju dominantne obrasce sekuritizacije i desekuritizacije, ${ }^{12}$ iako Buzan i saradnici (1998) razmatraju dinamiku bezbednosnog kompleksa u celini bezbednosnih sektora (holistički, homogeno), iako ne odbacuju mogućnost da se posmatra i dinamika pojedinačnih sektora (heterogeno). Na primer, kolektivni identitet može biti predmet sekuritizacije, ali se vojna i politička bezbednost uzimaju kao ključni pokazatelji regionalne bezbednosne dinamike - koja u delu spektra koji naginje neprijateljstvu (engl. enmity) ima najveći potencijal za izbijanje oružanih sukoba. U socijetalnoj bezbednosti, danas se može govoriti o obrascima prijateljstva (engl. amity) koji proističu iz osećaja sigurnosti partikularnih identiteta, ili o razvijanju novih identiteta jedne šire grupe koji potiskuju potencijal za izbijanje

\footnotetext{
${ }^{10}$ Bezbednost se obično shvata kao subjektivna i objektivna kategorija. Tako Arnold Volfers (Arnold Wolfers) bezbednost definiše kao odsustvo pretnje da će određene stečene vrednosti biti ugrožene ili odsustvo straha da će one biti ugrožene, čime se dolazi do shvatanja bezbednosti u subjektivnom i objektivnom smislu. U takvom shvatanju bezbednosti, ostavlja se mogućnost za subjektivističko i objektivističko shvatanje bezbednosti, ali je ona za Kopenhašku školu primarno intersubjektivni proces koji se konstituiše u odnosu između aktera u procesu sekuritizacije (Wolfers 1962).

${ }^{11}$ Sektorski pristup proučavanju bezbednosti je detaljno razrađen u: Buzan et al. 1998, na šta se pozivamo $u$ daljem toku rada.

${ }^{12}$ Sekuritizacija se u svom osnovnom značenju može odrediti kao imenovanje nečega bezbednosnom temom uz mogućnost preduzimanja vanrednih mera u cilju otklanjanja egzistencijalne pretnje. O tome videti: Buzan et al. 1998.
} 
oružanih sukoba. ${ }^{13}$ No, moguće je i izbijanje neprijateljstava kada se partikularni identiteti osećaju ugroženim od strane drugih, bilo da su oni unutrašnji bilo spoljašnji. Međutim, mi ovde smatramo da je holistički pogled na regionalnu bezbednost $u$ načelu celishodniji, dok se $u$ pojedinostima mogu analizirati različiti procesi sekuritizacije koji zahvataju pojedinačne sektore.

Teorija regionalnog bezbednosnog kompleksa ima osobeno shvatanje bezbednosnih regiona jer upućuje na poseban splet i vrstu odnosa između unutarregionalnih država i drugih subjekata (ili jedinica) koji pretežno konstituišu sopstvene percepcije, stanje i izglede bezbednosne dinamike. Na bezbednosnu dinamiku pretežno utiču države kao dominantni subjekti bezbednosti, uz prisustvo nedržavnih aktera čiji uticaj ne može biti zanemaren. Glavna pretpostavka autora TRBK jeste da se pretnje brže prenose preko kraćih udaljenosti, te će se mogući sukobi i celokupna bezbednosna dinamika ogledati na nekom geografskom prostoru srednje veličine. Taj prostor se naziva bezbednosni region koji, tek kada uzmemo $\mathrm{u}$ obzir njegove socijalne i materijalne odlike $u$ odnosu između njegovih jedinica, može poneti naziv bezbednosni kompleks. Uprkos trendovima tehnologizacije međunarodnih odnosa, smatramo da pretpostavka o teritorijalnosti regionalne bezbednosti ipak nije uzdrmana ovim trendom koji dodatno skraćuje vreme i intenzivira prostor u interakcijama ljudi, grupa i država.

Razlog zbog kojeg su se Buzan i Vejver okrenuli regionalnom nivou analize, kao najpogodnijem, jeste taj što su želeli da bolje razumeju strukturu globalne bezbednosti. Naime, njihov cilj je da se razume kako se dinamike različitih regiona uklapaju u globalnu dinamiku u kojoj učestvuju sve države i nedržavni akteri, ali koju dominantno oblikuju velike sile (Buzan and Waever 2003, 445). Pritom je iskustvo XX veka pokazalo da, kako oni primećuju, promene u polarnosti ne utiču na stvaranje

${ }^{13}$ Zanimljivo je da, recimo, proces evropske integracije može biti shvaćen kao funkcionalni čin, ali i stvaranje novog supranacionalnog identiteta, koji može, i ne mora, da bude shvaćen kao pretnja za nacionalne identitete država članica Evropske unije u očima nacionalističkih i populističkih političkih opcija. U novije vreme, činovi istupanja Velike Britanije iz Evropske unije („Bregzit“), porast populističke političke retorike u zemljama Srednje Evrope, poput Mađarske i Poljske, mogu biti posmatrani i kao deo procesa politizacije i sekuritizacije daljeg produbljivanja evropske integracije na tragu kriznog protivdiskursa o renacionalizaciji politike u drugoj deceniji ovog veka. 
bezbednosnih kompleksa, dok odnos globalnog i regionalnog nivoa utiče na stabilnost regionalnih bezbednosnih kompleksa (RBK) i "politiku globalne bezbednosne strukture" (Buzan and Waever 2003, 448). TRBK je bitan za proučavanje međunarodne bezbednosti jer u obzir uzima koncept bezbednosti koji je definisan i pogodan za teorijsko istraživanje i ispitivanje, tj. nije bezobalan, već je merljiv, proverljiv i spreman za ukrštanje sa drugim teorijskim konceptima. Za razliku od ustaljenog proučavanja međunarodne bezbednosti koje se uglavnom zasniva na nacionalnom i globalnom nivou, TRBK je prva teorija koja na sistematičan i sveobuhvatan način sagledava međunarodnu bezbednost nakon Hladnog rata sa polazišta koja ukrštaju strukturalni realizam sa globalističkim i konstruktivističkim teorijama.

Buzan i saradnici pišu da je „bezbednosni kompleks definisan kao skup država čije su glavne bezbednosne percepcije i problemi toliko povezani da se problemi njihovih nacionalnih bezbednosti ne mogu $\mathrm{u}$ razumnoj meri analizirati ili razrešiti odvojeno" $(1998,11-12) .{ }^{14}$ Po uzoru na neorealističku teoriju, oni smatraju da su RBK podsistemi i male anarhije koje imaju svoju strukturu kao i sistemi. ${ }^{15}$ Cilj je da se izbegne proizvoljnost u mapiranju RBK i uvaži zamisao TRBK o nepreklapajućem članstvu država u različitim regionalnim kompleksima (za razliku od Lejka i Morgana (1997)). ${ }^{16} \mathrm{Na}$ ovaj način se sprečava proizvoljnost i mnogostruki regionalni identiteti, te socijalna konstrukcija regiona koja predstavlja proizvod saobraćanja između država koje se "dogovaraju“ oko zajedničke pripadnosti nekom funkcionalnom prostoru, ili im biva nametnut neki zajednički regionalni imenilac.

Zato što su TRBK $u$ tesnoj vezi sa teorijom sekuritizacije (bezbednost kao govorni čin) i sa tada pojmljenom opadajućom ulogom države, a u

${ }^{14} \mathrm{U}$ izvornoj verziji definicija glasi: "A security complex is defined as a set of states whose major security perceptions and concerns are so interlinked that their national security problems cannot reasonably be analyzed or resolved apart from one another" (Buzan et al. 1998, 11-12).

${ }^{15}$ Tačnije, navodi se da su „bezbednosni kompleksi podsistemi - minijaturne anarhije - za sebe, i po analogiji sa potpunim sistemima oni poseduju sopstvene strukture“ (Buzan et al. 1998, 13).

${ }^{16} \mathrm{O}$ relativnosti članstva $\mathrm{u}$ regionima ilustrativno govori primer Hrvatske i njenog funkcionalnog, te simboličkog izdvajanja iz regiona Zapadnog Balkana koji je konstruisala EU nakon njenog ulaska u Evropsku uniju 2013. godine (uporediti sa: Buzan and Weaver 2003, 48). 
nameri da se teorija dodatno učvrsti, u knjizi Regions and Powers (2003) došlo je do delimične promene u definiciji RBK. Bezbednosni kompleks je ovoga puta određen kao skup jedinica (a ne država), gde se među jedinicama mogu naći i nedržavni akteri. Umesto njihovih bezbednosnih problema ili bezbednosnih percepcija, sada $u$ fokus dolaze međusobno povezani i uslovljeni procesi sekuritizacije i desekuritizacije (a ne bezbednosnih problema) koji ne mogu da se posmatraju odvojeno. Drugim rečima, "bezbednosni kompleksi su regioni viđeni kroz optiku bezbednosti“ (Buzan and Waever 2003, 43-44). U zavisnosti od toga da li bezbednost posmatramo sveobuhvatno ili na nivou pojedinačnih sektora, kompleksi mogu biti homogeni i heterogeni. Kada je reč o pominjanju jedinica analize, autori Kopenhaške škole svrstavaju države kao glavne jedinice koje sačinjavaju komplekse - zbog jednostavnosti i lakšeg razumevanja, čime se ne negira njihov stav protiv državocentričnosti (Buzan et al. 1998). Oblici spoljašnjih uticaja na tok bezbednosne dinamike predstavljaju delimični ili totalni uticaj velikih sila na bezbednosnu dinamiku drugih regionalnih kompleksa čime se ona oblikuje ili obustavlja spolja. Ti oblici su poznati pod nazivom prekrivač i prodor. Ovde bismo dodali i to da jedan oblik uticaja na unutarregionalnu bezbednosnu dinamiku može predstavljati i delanje velike sile $u$ centriranom RBK, što se može razumeti i kroz pojam sfera uticaja (npr. Rusija u Postsovjetskom RBK).

Nakon pozicioniranja regiona kao upotrebljivog nivoa analize $u$ stvaranju regionalne bezbednosne dinamike, opravdano je postaviti pitanje da li regioni mogu da budu akteri sa posebnim kvalitetom delovanja? Buzan i saradnici (1998) odgovaraju na ovo pitanje tako što tvrde da regioni nisu samostalni akteri. Regionalnu bezbednost Kopenhaška škola posmatra uzimajući nedržavocentričnu perspektivu kroz pluralizam aktera, ali gde se struktura međunarodnog sistema i dalje određuje u odnosu na države. One su te koje primarno određuju pravila ponašanja unutar sistema. Značajno je imati na umu odnos između strukturalnog realizma i socijalnog konstruktivizma u teorijama međunarodne bezbednosti. Iako je međunarodni sistem prema strukturalnom realisti Kenetu Volcu suštinski državocentričan, konstruktivistički teoretičar Aleksandar Vent (Alexander Wendt) obrazlaže da današnji svet to ipak nije. Vent strukturu međunarodnog sistema sagledava drugačije od Volca, smatrajući da države nisu najvažniji, niti jedini, već dominantni akteri. Država je, smatra Vent, ključna kada se radi o "globalnom regulisanju nasilja“ te da je ona „primarni prenosnik nasilja kroz koga efekti drugih aktera koji regulišu 
nasilje bivaju usmereni na svetski sistem“ (1999, 9). Time se, doduše posredno, ostavlja mogućnost za tumačenje mesta i uloge regiona kao mogućih aktera ili delatnika u međunarodnoj bezbednosti.

\section{REGIONI U STUDIJAMA BEZBEDNOSTI NAKON TRBK-A: PROSTORI SINTEZE ILI POPRIŠTE NOVIH SUKOBA?}

Komentarišući aktuelne rasprave o regionalnoj bezbednosti, Buzan i Vejver su saglasni da je ostvaren napredak u postavljanju regionalnog nivoa analize kao pogodnog za posmatranje i analizu međunarodne bezbednosti. To ne znači da je regionalni nivo jedini, već da je neizostavan, a često i „najvažniji“ deo međunarodne bezbednosne analize (Buzan and Waever 2003, 463). Tako navode i upotrebu koncepta regionalnog bezbednosnog kompleksa kod Lejka i Morgana sa ranije pomenutom idejom regionalnih poredaka, ali podvlače da ova dvojica autora ne razvijaju teorijski pristup koji značajnije odstupa od neorealističkog pogleda na međunarodnu bezbednost. ${ }^{17}$ Buzan i Vejver ističu da njihova teorija ima veći domet i nudi okvir za iznošenje predviđanja, što povećava njenu praktičnu upotrebljivost. Jedan od zadataka teorije je da, pored sistematičnog sagledavanja empirijskih činjenica (tzv. evropsko shvatanje teorije), ponudi i okvir za predviđanje putem utvrđivanja kauzalnih veza (tzv. američko shvatanje teorije). Kako oni zaključuju, TRBK bi pre mogla da prođe kao teorija u evropskom shvatanju, dok utvrđivanje kauzalnih veza i uzročnosti zahteva još rigoroznije podvrgavanje proveri njenih hipoteza, što u složenim društvenim naukama nije uvek moguće sprovesti (Buzan and Weaver 2003, 83).

Od objavljivanja knjige Regions and Powers 2003. godine, nastavlja se interesantan razvoj regionalističkih pristupa u međunarodnoj bezbednosti. Iako su autori nudili kritike i pohvale TRBK (Hoogensen 2005; Acharya 2007; Kovačević 2013), ova teorija postala je ugaoni kamen proučavanja regiona, s obzirom na to da je malo ko nakon objavljivanja knjige mogao da praktikuje regionalistički pristup, a da je barem ne uzme u obzir. Čak i pristupi koji su se javili pre ili $u$ isto vreme kada i TRBK (npr. regionalni poreci i bezbednosne zajednice), uticali su ili su se tokom prve dve decenije XXI veka menjali pod uticajem TRBK. Sinteza konstruktivizma i realizma kod TRBK učinila je ovu

${ }^{17}$ Za kritiku pogledati: Buzan and Weaver 2003, 78-79. 
teoriju pogodnom za povezivanje i sintezu sa drugim pristupima. Savremene pristupe na tragu TRBK odlikuje potreba da se neke neuravnoteženosti i nedostaci TRBK prevaziđu. Sveukupno, savremeni pristupi regionima $u$ studijama bezbednosti pokazuju, pre svega, svest o potrebi spajanja realističkih i konstruktivističkih struja kako bi se dala što potpunija perspektiva o proučavanim bezbednosnim problemima. Otuda ove teorije pokazuju visok nivo prilagodljivosti i mogućnosti učenja od rivalskih pristupa. Istovremeno, savremene teorije, iako u riziku, nisu eklektične, jer sinteze različitih pristupa dovode do kombinovanja temeljnih teorijskih principa, a ne naporednog korišćenja različitih perspektiva. ${ }^{18}$ Smatramo da je ovakav fon razvoja teorije jedno od nasleđa TRBK, jer je ona uspešno afirmisala konvergenciju pristupa koja vodi do značajnih empirijskih uvida.

Klasifikovanje regionalističkih pristupa u međunarodnim odnosima nije lak zadatak, jer postoji mnoštvo pristupa koji se zasnivaju na realističkim, liberalnim i konstruktivističkim tradicijama. Kako Vajrinen (2003) ističe, regionalistički pristupi postojali su na dva koloseka - funkcionalističkom i konstruktivističkom. Sa druge strane, mi smo u prethodnom delu teksta istakli da TRBK predstavlja prvi korak ka sinergiji tradicija u jedan koherentan okvir kroz snažnije oslanjanje na konstruktivističko shvatanje regiona, a uz svest o značaju funkcionalističkog pristupa. Ključni kriterijum u izboru teorija koje obrađujemo u nastavku jeste njihova sposobnost da komuniciraju sa TRBK ili da konceptualno nadograđuju ili prilagođavaju aparat TRBK. Prema tome, u analizu su ušle teorije regionalnih poredaka (Katzenstein 2005; Frazier and Stewart-Ingersoll 2010), regionalnih bezbednosnih zajednica (Adler and Barnett 1998) i regionalnih "multipleks" međunarodnih poredaka (Acharya 2014; Acharya 2018). Ove teorije često dele zajedničke tradicije, npr. teorija regionalnih bezbednosnih poredaka zasniva se na realizmu i (kod Kacenstajna) konstruktivizmu, dok je ideja regionalnih bezbednosnih zajednica zasnovana na liberalizmu i konstruktivizmu, a "multipleks" međunarodnih poredaka dominantno na konstruktivizmu. Ipak, konceptualna otvorenost ovih teorija omogućila je istraživačima da na njihovim temeljima i uz kritiku TRBK sintetišu nove teorijske okvire koji daju potpunije uvide u strukture i dinamike svetskih regiona.

${ }^{18}$ O eklekticizmu u međunarodnim odnosima, videti: Sil and Katzenstein 2010. 


\section{Regionalni bezbednosni poreci}

Ideju regionalnih bezbednosnih poredaka prvi su razradili Lejk i Morgan (1997). Značajan doprinos dao joj je i Kacenstajn (2005) tokom prošle decenije, analizirajući američku moć u stvaranju svetskih regiona. Lejk i Morgan vide regione kao tesno povezane celine država, gde „u smislu njihove bezbednosti, akcije bilo koje članice i značajan razvoj događaja u vezi sa bezbednošću unutar bilo koje države imaju značajan uticaj na druge" (1997, 12). Njihova ideja regiona orijentisana je na upravljanje međudržavnim konfliktima (Lake and Morgan 1997, 40). Regioni stoga mogu da budu u različitim formacijama upravljanja međudržavnim konfliktima, a koje ovi autori posmatraju kao kontinuum kojim se regioni progresivno kreću ka sve manjoj mogućnosti međudržavnih sukoba (Lake and Morgan 1997, 33, 39). Takvih formacija je pet: međusobno ograničavajuće sile (engl. power restraining power), koncert velikih sila (engl. great power concert), kolektivna bezbednost (engl. collective security), pluralna bezbednosna zajednica (engl. pluralistic security community) i integracija (engl. integration) (Lake and Morgan 1997, 32-33). Kao ključnu pokretačku silu svake formacije regulisanja međudržavnih sukoba, Lake i Morgan vide projekciju moći nacionalne države $(1997,39)$, čak i kada su u pitanju razvijeni oblici upravljanja poput pluralne bezbednosne zajednice. Nasuprot Lejku i Morganu, Kacenstajn (2005) donosi jedan eklektičan teorijski okvir koji se zasniva na ideji da SAD prema projekciji sopstvene moći oblikuju svetske regione. Razlike u tome kako se ova moć projektuje i kakve posledice ona ima stvaraju drugačiju arhitekturu regiona, npr. u Evropi i Aziji (Katzenstein 2005; Sbragia 2008). Ključne razlike između ovih autora jesu da Lejk i Morgan dozvoljavaju veći stepen autonomije lokalnih sila $u$ definisanju regiona, dok je kod Kacenstajna ključna uloga jedne supersile i njenih namera u regionu. Druga razlika je u tome što Lejkov i Morganov model regiona omogućava poređenje svetskih regiona, dok su kod Kacenstajna naglašene njihove specifičnosti.

Dva interesantna doprinosa koja kritički nastavljaju tradiciju Lejka i Morgana dali su Rodrigo Tavareš (Rodrigo Tavares) 2008. godine u vidu teorije regionalnih klastera mira i bezbednosti (engl. Regional Peace and Security Cluster [RPSC]), kao i Derek Frejžer (Derrick Frazier) i Robert StjuartIngersol (Robert Stewart-Ingersoll) 2010. godine kroz okvir regionalnih sila i bezbednosti (engl. Regional Powers and Security Framework [RPSF]). Ova dva okvira novijeg datuma kroz kritiku komuniciraju sa teorijskim okvirom 
TRBK, ali i idejom regionalnih bezbednosnih poredaka Lejka i Morgana. U kritici Lejka i Morgana, kod oba teorijska okvira očigledan je otklon od ideje da se regioni kreću linearnim i progresivnim tokom kroz različite formacije do sve efikasnijeg upravljanja međudržavnim sukobima. Naprotiv, ovi okviri vide da regionalne formacije zavise od strukturnih (Tavares 2008), odnosno strukturnih i identitetskih činilaca (Frazier and Stewart-Ingersoll 2010). Oba modela identifikuju i ključne nedostatke okvira TRBK koje teže da unaprede i to rade bilo kroz naglašeno insistiranje na strukturama, bilo kroz produbljivanje konstruktivističkih komponenti okvira. Kritika koju daju Frejžer i Stjuart-Ingersol fokusira se na ulogu sila u regionalnoj bezbednosnoj dinamici. Ovi autori smatraju da okvir TRBK ne može da nam kaže na koji način se „identifikuju regionalne sile, kako se ispituju njihove jedinstvene funkcije i kako ove funkcije utiču na regionalne poretke“ (Frazier and Stewart-Ingersoll 2010, 733).

Nijansiranu i promišljenu kritiku Buzanovog i Vejverovog pristupa daje Tavareš (2008). Prema njegovom mišljenju, postoje četiri ključna problema sa teorijskim okvirom TRBK koji se zasnivaju na kritici sekuritizacije kao osnovnog procesa kroz koji se kristališe dinamika regiona. Prvi problem je da čin sekuritizacije ne govori ništa o konkretnim instrumentima ili mehanizmima koje podrazumeva kršenje regularnih pravila političkog života (Tavares 2008, 108). Drugi problem je da obrasci sekuritizacije ne govore mnogo o realnim obrascima nasilja i mira u regionima, te da tri formacije koje daju Buzan i Vejver nisu pouzdan pokazatelj dinamike regionalne bezbednosti (Tavares 2008, 109). Treći i četvrti problem su mali broj varijabli u okviru TRBK, što na kraju ne daje nijansiranu sliku kako od neprijateljstva nastaju prijateljstva; za tako nešto je, prema Tavarešu, potreban značajno veći broj varijabli u modelu $(2008,109)$.

Ključna odlika Tavarešovog pristupa RPSC jeste da svi regioni, ${ }_{19}^{19}$ uprkos svojim specifičnostima i divergentnim dinamikama, sadrže zajednički skup strukturalnih komponenti. Za Tavarešov model ključno je mapiranje ovih struktura čiji odnos, na kraju, daje empirijsku realnost regiona. Za razliku

\footnotetext{
${ }^{19}$ Tavareš region shvata gotovo funkcionalistički, kao npr. u sledećoj rečenici: „,Ovo je logika iza regionalnih klastera mira i bezbednosti (RPSC), definisanih kao skupovi mirovnih i bezbednosnih odnosa koji se javljaju na širokoj teritoriji (regionu), a koje pokreću agensi koji deluju na različitim nivoima regionalne integracije i koriste različite instrumente da promene obrasce bezbednosti, konflikta i pozitivnog mira" $(2008,116)$.
} 
od prethodećih pristupa na tragu regionalnih bezbednosnih poredaka, Tavareš razlikuje bezbednost kao upravljanje pretnjama i mir kao upravljanje nasiljem. Iako je model regiona kod RPSC deskriptivan, istovremeno je i dinamičan jer pretpostavlja da se promenom u samim strukturama, kao i odnosom među njima, menja i empirijska stvarnost regiona (Tavares 2008).

Kao ključne strukture modela ističu se: a) teritorija koja smešta odnose svih drugih komponenti, a koji se na regionalnom nivou mogu registrovati; b) komponente kao što su agensi mira i bezbednosti, obrazac bezbednosti, instrumenti mira i bezbednosti, obrazac konflikta, obrazac pozitivnog mira i nove regionalne integracije; c) veze među komponentama kao krajnja struktura (Tavares 2008, 116-117). U odnosu na vrednost samih komponenti i veze među njima, Tavareš predlaže da se regionalni klasteri mogu podeliti $\mathrm{u}$ četiri kategorije: fragmentisane regione (engl. regional fragmentations), regionalne koalicije (engl. regional coalitions), regionalne zajednice (engl. regional communities) i regionalna upravljačka uređenja (engl. regional governmental polities) (2008, 117-118). Kako RPSC model ne poznaje ideju linearnog napretka, nabrojani tipovi mogu da se razumeju samo kao kristalizacije trenutnih odnosa među komponentama koje su promenljive $u$ vremenu. Ključna prednost ovog modela jeste veoma jasna razrađenost komponenti koje ga čine pogodnim za uporedna ili kvantitativna istraživanja. ${ }^{20}$ Ono što se može zameriti ovom pristupu jeste da, od svih obrađenih, najviše naginje eklekticizmu. Komponente modela su skladno tome (re)definisane i uklopljene $\mathrm{u}$ koherentnu celinu, tako da ovaj model ima najmanje sluha za tekovine konstruktivizma, zbog čega ostajemo uskraćeni za uvid kako predloženi niz delatnika (od individualnih do regionalnih) konceptualizuje sopstveno delanje u regionalnim odnosima.

Frejžer i Stjuart-Ingersol (2010) razvijaju svoj okvir regionalnih sila i bezbednosti (RPSF) iz prepoznate potrebe da se u razumevanju regionalne bezbednosne dinamike jasnije integrišu tekovine konstruktivizma i realizma. Ovi autori prepoznaju da je odnos kapaciteta vojne moći sila bitan u bezbednosnoj dinamici regiona, ali da su jednako determinišuće njihove preuzete uloge i identiteti. Frejžer i Stjuart Ingersol tako smatraju da se

${ }^{20}$ Treba ipak imati na umu da samo testiranje modela nije nužno pokazatelj adekvatnosti modela, već je pogodnije model shvatati kao mapu koja neke delove stvarnosti izostavlja u težnji da obradi neki konkretan problem (Clarke and Primo 2012), kao što su, u ovom slučaju, promene mira i bezbednosti u svetskim regionima. 
dinamika regiona može objasniti kroz tri ključne eksplanatorne varijable: regionalnu strukturu, regionalne uloge moći i regionalne orijentacije moći (2010, 731). Nadograđujući konstruktivistički argument, autori smatraju da regionalni akteri mogu da deluju u ulogama vođe (engl. leadership), staratelja (engl. custodianship) i zaštitnika (engl. protection), dok njihove orijentacije mogu biti prema postojećem stanju (status quo ili revizija), saradnji (unilateralnoj ili multilateralnoj) i oblikovanju regiona (reaktivnom ili proaktivnom) $(2010,732,748)$.

Kao jednu od bitnih odlika ovog modela, autori predstavljaju ulogu izvan-regionalnih velikih sila, iako njihov ključni fokus ostaje na regionalnim silama. Tako izvan-regionalne velike sile mogu da budu neaktivne u nekom regionu, ali mogu i da podignu moć određene regionalne sile. Velike sile takođe svojim ponašanjem mogu da utiču na postupke regionalnih sila, dok je krajnji vid njihovog uticaja kompletno strukturiranje regiona. Ipak, ključna uloga regionalnih sila je $\mathrm{u}$ tome da su one prema svojim kapacitetima najverovatniji zainteresovani činioci bezbednosne dinamike regiona, iako njihov angažman $u$ tome zavisi od načina na koji grade i vide sopstvenu ulogu u regionu (Frazier and Stewart-Ingersoll 2010).

Kombinujući realističku i konstruktivističku perspektivu, dvojica autora tvrde da regioni mogu da zauzimaju različite formacije u odnosu na to kako regionalne sile strukturišu raspodelu moći u odnosu na svoje kapacitete i uloge praćene orijentacijama. Moguće je prepoznati pet ovakvih formacija: hegemonu formaciju (engl. hegemonic), kolektivnu bezbednost (engl. collective security), međusobno ograničavajuće sile (engl. power restraining power), koncert (engl. concert) i nestrukturisane formacije (engl. unstructured) (Frazier and Stewart-Ingersoll 2010, 735). Kao i kod Tavareša, kretanje regiona iz jedne formacije $\mathrm{u}$ drugu nije progresivno, već je odraz odnosa ključnih eksplanatornih varijabli. RPSF kao svoju najveću manu ima orijentisanost na države kao ključne aktere regionalne bezbednosti, bez uključivanja regionalnih ili međunarodnih organizacija. Kao ključna prednost $u$ odnosu na Tavarešov model može se uzeti snažnije oslanjanje na konstruktivizam koji u RPSF unosi uloge i orijentacije kao ključne faktore regionalne bezbednosne dinamike.

\section{Regionalne bezbednosne zajednice}

Ideju bezbednosne zajednice, koja je decenijama starija od teorije sekuritizacije i teorijskog okvira TRBK, prvi je izložio Karl Dojč (Karl 
Deutsch) 1954. godine u knjizi Political Community at the International Level: Problems of Definitions and Measurement. Prema ovom autoru, bezbednosna zajednica je: „grupa koja je postala integrisana, gde je integracija definisana kao postignuće osećaja zajednice, praćeno formalnim ili neformalnim institucijama i praksama, dovoljno jakim i raširenim da osiguraju mirne promene među članicama grupe sa 'razumnim stepenom' sigurnosti u toku 'dugog vremenskog perioda'" (Deutsch 1954, 33). Od samog nastanka koncepta bezbednosne zajednice, pokazalo se da je adekvatan $u$ povezivanju različitih tradicija u međunarodnim odnosima (Koschut 2014). Čak i pregledom pristupa regionalnih bezbednosnih poredaka, jasno je da i realistički pristup Lejka i Morgana (1997), kao i kombinovani relističkokonstruktivistički pristup Buzana i Vejvera (2003), te Frejžera i StjuartIngersola (2010) kao komponente svojih modela imaju bezbednosne zajednice. Iako ovi autori ne konceptualizuju bezbednosnu zajednicu na isti način, svima im je zajedničko da akteri bezbednosne zajednice računaju na mirne promene $u$ bezbednosnoj dinamici regiona (upor. Ejdus 2018, 2). Iako prilagodljiva različitim tradicijama, ideja bezbednosne zajednice teško da može biti interfejs teorija jer i sama funkcioniše pre kao „skup pretpostavki o miru u međunarodnim odnosima“" (Puchala 1981, 150 navedeno prema Koschut 2014, 10), nego kao celovita teorija. Korake ka daljem razvoju ideje bezbednosne zajednice u celovitu teoriju dali su Emanuel Adler i Majkl Barnet (Emanuel Adler and Michael Barnett) u knjizi Security Communites iz 1998. godine. Ovi autori su Dojčovu liberalnu, kantijansku ideju dopunili novim sociološkim razumevanjem izgradnje bezbednosne zajednice zasnovane na ideji zavisnosti od pređenog puta (engl. path-dependence) (Ejdus 2018, 2). Prema ovim autorima, bezbednosne zajednice nastaju istorijskim procesima konceptualizovanja i institucionalizacije očekivanja mirnih promena (Adler and Barnett 1998, 49 navedeno prema Ejdus 2018, 2). U perspektivi Adlera i Barneta, moguće je razlikovati tri vrste bezbednosnih zajednica: nastajuće (kod kojih saradnja među državama ne teži bezbednosnoj zajednici), uzdižuće (kod kojih postoje mreže institucija, mreže koordinacije i začeci zajedničkog identiteta) i zrele (kod kojih postoji duboka institucionalizacija, formiran identitet $\mathrm{i}$ međusobna očekivanja o mirnom rešavanju sporova) (Ejdus 2018, 2).

Originalna zamisao bezbednosne zajednice podrazumeva da je bezbednosna zajednica specifična konfiguracija bezbednosne dinamike regiona. Ova zamisao ugrađena je i u okvir TRBK, ali i pristupe bezbednosnih poredaka. Konfiguracija se kao takva nalazi na duži koja se 
često proteže od anarhije i sukoba ka miru i gde je bezbednosna zajednica poistovećena sa mirom i saradnjom (upor. Adler and Greve 2009, 63-64). Kod svih do sada nabrojanih pristupa bezbednosna zajednica je ishod odnosa ključnih strukturnih komponenti regiona (Adler and Greve 2009, 65). Adler i Griv (2009) smatraju da bezbednosne zajednice kao ishodi ne daju potpuno objašnjenje regionalnih bezbednosnih dinamika te se oni okreću konceptu prakse $\mathrm{u}$ međunarodnim odnosima. ${ }^{21}$ Ovi autori konceptualizuju bezbednosnu zajednicu kao jedan od mehanizama bezbednosnog upravljanja regionima koji nastaje kroz politike i ponašanja na nivou jedinice regiona (Adler and Greve 2009, 67). Tako bezbednosna zajednica predstavlja paletu praksi koju akteri u međuregionalnim odnosima mogu da koriste. Iako bezbednosna zajednica i ravnoteža moći (kao drugi mehanizam) zadržavaju svoje različitosti, u praksi jednog regionalnog aktera može doći do preklapanja (engl. overlap), odnosno korišćenja praksi koje pripadaju različitim mehanizmima u različitim bezbednosnim prilikama (Adler and Greve 2009, 62-63). Ovi autori smatraju da izbor praksi zavisi od sektora primene, zatim od dela državne administracije koji primenjuje određenu politiku i, na kraju, prakse mogu zavisiti od konkretnog problema na koji se politike primenjuju (Adler and Greve 2009, 75-78). Kao bitne komponente ove ideje su prostornost (spacijalnost), odnosno vremenitost (temporalnost) jer izbor praksi zavisi od toga u kom regionu akter (koji može biti izvan-regionalni) deluje, kao i što zavisi od vremena u kom se praksa primenjuje (Adler and Greve 2009).

Predložena razrada ideje o preklapanju praksi ključan je doprinos Adlera i Griva istraživanjima u međunarodnim odnosima. Za razliku od prethodnih (TRBK i regionalnih bezbednosnih poredaka), ideja bezbednosne zajednice kao mehanizma upravljanja konstruiše granice regiona kao fluidne i promenljive. Naime, pristup TRBK zasniva se na tome da jedna država ne može biti članica više od jednog regionalnog bezbednosnog kompleksa, što granice regiona čini teško promenljivim (Buzan and Waever 2003). Pristupi regionalnih bezbednosnih poredaka ovu tekovinu TRBK nisu kritikovali, često je podrazumevajući. Zajedno uzevši, prethodno obrađeni pristupi tako mogu da se okarakterišu kao sistemski jer su ovi okviri pogodni za analizu i regionalnih bezbednosnih kompleksa

\footnotetext{
${ }^{21} \mathrm{Za}$ detaljnije o takozvanom „praktičkom zaokretu“ (engl. practice turn) u međunarodnim odnosima videti: Pouliot (2008). Adler i Griv praksu definišu kao „'performans sa kompetencijom' koji je kao takav prepoznat" $(2009,66)$.
} 
kao celina, ali i pojedinačnih državnih i nedržavnih aktera. Nasuprot ovom, Adler i Griv pretpostavljaju da regioni pored značaja geografije, vrednosti i normi imaju i dimenziju praktičkog stvaranja $(2009,81)$. Ova dimenzija znači da se granice regiona definišu i kroz način na koji se „čini“ bezbednost (engl. doing security) (Adler and Greve 2009, 81). Sama raznovrsnost praksi i mogućnost da različite i neusaglašene prakse proiziđu iz istovetnih vrednosno-normativnih okvira čine osnovu poroznosti i promenljivosti granica regiona (Adler and Greve 2009, 82). Primeri koje daju ovi autori (npr. neslaganja u praksi vođenja rata protiv terorizma između evropskih članica NATO-a i SAD) govore o tome da je okvir prakse pogodan za analizu razmimoilaženja i neslaganja u određenim regionima koji dele slične vrednosti, koliko i uporednoj analizi regiona. Prema našem mišljenju, ovaj okvir pruža osnovu za sistematsku analizu, ali i za veoma preciznu analizu regionalnih ili izvan-regionalnih aktera u nekom regionu. Oslanjanje na koncept prakse, kao deo mehanizama upravljanja, ispravlja totalizujuće tendencije formacija relativno trajnih stanja regiona kod TRBK i pristupa regionalnih bezbednosnih poredaka, što u krajnjoj instanci daje nijansiraniju sliku o bezbednosnoj dinamici regiona. Kritika koja se može uputiti ovom okviru je da nedovoljno razrađuje zavisnost regionalnih formacija od praksi te ostaje nejasno u kojoj meri prakse imaju sposobnost da menjaju norme i vrednosti ili pak obrasce prijateljstva/neprijateljstva u jednom regionu. ${ }^{22}$

\section{Regionalni "multipleks" međunarodni poreci}

Značajan teorijski doprinos proučavanju svetskih regiona dao je Amitav Ačarija (Amitav Acharya) $(2014 ; 2018)$ kroz ideju regionalnih „multipleks“ poredaka. Ovaj autor svoje viđenje o bezbednosnoj dinamici regiona gradi oslanjajući se na konstruktivizam, institucionalizam i post-kolonijalnu misao. Tri struje na koje se oslanja Ačarijina misao ujedinjuje istorijska perspektiva i ideja da institucije imaju moć da konstruišu regionalne poretke, dok oslanjanje na post-kolonijalnu misao usmerava celu teorijsko konstrukciju ka poziciji da institucije i poreci nisu samo preslikane institucije Zapada, već da nose distinktivne kvalitete. Ačarija svoju ideju regionalnih „multipleks“

\footnotetext{
${ }^{22}$ Sličnu kritiku ideje prakse, samo na primeru proučavanja takmičarskih autoritarnih režima, videti u: Pepinsky 2020.
} 
poredaka (2014) gradi proučavajući transformaciju američke moći nakon Hladnog rata i, pre svega, razvoj bezbednosne arhitekture Jugoistočne Azije.

Kao ključnu razliku multipleks poredaka, $\mathrm{u}$ odnosu na regionalne bezbednosne poretke i regionalne bezbednosne zajednice, izneli bismo naglašen istoristički pristup. Ovaj pristup ima za cilj da ukaže kako je istorija regionalizacije uticala na stvaranje i promene regionalnih bezbednosnih dinamika. Pozivanje na istoriju povezuje ovaj okvir sa TRBK, koja i sama (iako ne tako naglašeno) poziva na istorijska kretanja ne bi li objasnila obrasce sekuritizacije i desekuritizacije koji stvaraju bezbednosne dinamike regiona. Druga ključna razlika je pozivanje na post-kolonijalnu misao koja nije prisutna ni u jednom od rivalskih pristupa. U osnovi to znači da nijedan od rivalskih pristupa ne uzima iskustvo kolonizacije kao faktor koji oblikuje obrasce regionalizacije. Shodno tome, iskustva Evrope i Severne Amerike ne moraju da budu vodiči za transformacije regiona na Globalnom Jugu. Tako ideja "bezbednosne zajednice“ kao očekivanog i svima poželjnog ishoda iz perspektive bivših kolonizatora gubi svoju primamljivost u očima bivših kolonizovanih društava koja visoko vrednuju sopstvenu samostalnost (Acharya 2014).

Kao osnova za razumevanje regionalnih „multipleks“ poredaka uzimamo ideju poretka u međunarodnim odnosima i načina na koji se američka moć transformiše nakon Hladnog rata. Osnovu stvaranja regiona Ačarija (2018) vidi u različitom shvatanju ideja poput suvereniteta ili nacionalne bezbednosti. Iako ove ideje potiču iz evropskog i američkog političkog konteksta, njihovo prenošenje putem kolonizacije uzrokovalo je različita tumačenja, lokalizovanja i prilagođavanja te se ne može reći da imaju jednako značenje i značaj za sve aktere međunarodnog sistema. Preosmišljavanje zapadnih ideja za Ačariju (2018) predstavlja jedan vid dejstvenosti (agensnosti ili delatništva) koji bivšim kolonizovanim zemljama daje mogućnost da utiču na dinamiku sopstvenih regiona kroz postavljanje lokalnih normi i praksi kojima spoljašnji učesnici moraju da se prilagođavaju ne bi li postali relevantni činioci tog regiona. Poreklo dejstvenosti post-kolonijalnih zemalja leži u tome da liberalni američki svetski poredak (American World Order) ${ }^{23}$ nije bio univerzalan i da je temeljno preoblikovao bezbednost u Severnoj Americi i Evropi, ali ne i u ostatku sveta (Acharya 2014). Američki svetski poredak je za Ačariju u

\footnotetext{
${ }^{23}$ Pod ovim terminom, Ačarija podrazumeva ne samo unipolarni momenat već i dugoročne fizičke i normativne posledice američke sile (upor. Acharya 2014, 4).
} 
opadanju, a pitanje o tome kako će se dalje razvijati međunarodna bezbednost ostaje otvoreno. Ključno je da će u oblikovanju regionalnih dinamika uloga SAD ostati značajna, iako one neće moći da nameću normative funkcionisanja kao u vreme unipolarnog momenta (Acharya 2014). Sa druge strane, sile koje osporavaju američku hegemoniju nisu dovoljno snažne da bi to uradile na globalnom nivou, što ih usmerava na lokalnije područje delovanja poput regiona (Acharya 2014).

Ačarijin pristup se od realizma razlikuje jer daje prednost osporavanju američke hegemonije na idejnom i normativnom, a ne na vojnom planu. Takođe, "multipleks" poredak predviđa da regionalni akteri imaju mogućnost da se odupru stvaranju sfera uticaja spoljnih velikih sila upravo kroz dizajniranje regionalnih "pravila igre“. Pristajanje na ta pravila igre može da legitimizuje regionalne sile u pokušajima da uđu u red velikih sila (poput Kine i njenog pristajanja na oblike saradnje koje nudi ASEAN) (Acharya 2014).

Upravo opadanje američke moći je za Ačariju ključan faktor uzdizanja regionalnih sila. Kako ove sile nisu same dovoljno moćne da se nametnu na svetskom nivou, regioni su domeni projekcije njihove moći. Značaj regiona kao poprišta delovanja velikih sila je u tome što njihovo delovanje i legitimnost na globalnom bezbednosnom planu zavisi od načina na koji deluju u regionima, gde postojanje regionalnih sila upućuje velike sile na saradnju sa regionalnim (Acharya 2018). Kao ključnu komponentu regiona, Ačarija ističe njihovu kompleksnost. Naime, regioni su često formirani kroz organizacije koje su grupe zemalja okupljale oko nekih pitanja, ali je razmeravanje regiona po različitim sektorima (ekonomskom ili bezbednosnom) okupljalo različite grupe država (Acharya 2014). Kako su vremenom organizacije počele da se prilagođavaju novonastalim problemima i bave pitanjima koja nisu bila na prvobitnoj agendi, tako Ačarija navodi da je ekonomska organizacija APEC (engl. Asia-Pacific Economic Cooperation) dala značajan doprinos rešavanju sukoba u Istočnom Timoru (iako je prvobitno zamišljena kao ekonomski forum) $(2014,88)$. Iako značajni, regioni nisu pokretač dinamike međunarodnih odnosa, već su samo ogledalo „rastuće kompleksnosti i preklapajuće raznolikosti gde lokalno i regionalno konstruisanje koncepata i pristupa poretku ima veći značaj nego što mu pridaju tradicionalni međunarodni odnosi“ (Acharya 2018, 2).

Da bi adekvatno opisao ovu rastuću kompleksnost i međuzavisnost svetskih regiona, Ačarija je skovao termin „multipleks“ poretka. Ovaj 
termin koristi $\mathrm{u}$ analogiji sa multipleks bioskopom (Acharya 2014). Korisnost ove metafore je $\mathrm{u}$ tome što multipleks podrazumeva da jednoj zgradi postoji mnoštvo velikih i malih sala pod jednim krovom te da $\mathrm{u}$ njima istovremeno mogu biti prikazivani različiti filmovi (Acharya 2014). Za međunarodne odnose, ova metafora kazuje da sve države ipak funkcionišu u okvirima zajedničke globalne bezbednosne arhitekture, dok svaki region može da pušta "svoj film“ (sa specifičnom publikom i svojim scenarijima) bez mnogo obraćanja pažnje na "filmove“ u najvećim salama, što znači da regioni imaju stepen autonomije u određivanju kojim idejama će se voditi u sopstvenom organizovanju. Ačarija (2014) naglašava da "multipleks" sistem od multipolarnosti razlikuje insistiranje na međuzavisnosti jedinica, a ne broju sila. "Multipleks" je, takođe, decentralizovaniji od multipolarnog sistema jer zahtevi koje regionalni akteri nameću spoljnim akterima sprečavaju kolektivnu hegemoniju velikih sila (Acharya 2014). Za ključne determinante regionalne bezbednosne dinamike u multipleks sistemu, Ačarija navodi moć, geografski opseg regiona, vođstvo regiona i vreme $(2014,9)$. Kao krajnju perspektivu "multipleks" poretka on uvodi ideju regionalnih svetova (engl. regional world perspective) (Acharya 2014). Ovim terminom Ačarija želi da naglasi kako su izvori moći i ideja u regionima difuzni i podeljeni među različitim akterima. U ovoj perspektivi, regioni su promenljivi geografski i kulturno $\mathrm{i}$ istovremeno nisu ni samodovoljni entiteti, a ni stvoreni spolja (Acharya 2014). Sam autor ovu ideju sumira rečima da je „moć važna, ali lokalni odgovori na tu moć mogu biti još važniji u konstruisanju regionalnih poredaka“ $(2014,81)$.

Najznačajniji doprinos perspektive „multipleks“ regionalnih poredaka studijama regionalne bezbednosti jeste taj da regioni nisu istovrsne jedinice (engl. like units). Svaki region stvara sopstvenu institucionalnu arhitekturu koja je odgovor na neke kontekstualne specifičnosti regiona, dok rivalski pristupi (delimično sa izuzetkom Adler and Greve (2009)) regione konstruišu kao istovrsne jedinice koji dele kompletno iste skupove struktura koji u svakom regionu imaju istu težinu. Ipak, Ačarija (2018) predlaže da se kao osnova shvatanja regionalne dinamike umesto skupa istovrsnih struktura posmatra istorijski proces stvaranja regionalnih institucija. Tako se kao bitni činioci izdvajaju istorija, osnivački ciljevi, političke strukture i obrasci odnosa sa spoljnim silama (Acharya 2014, 94). Prema Ačariji, regionalna bezbednosna dinamika razume se tek $u$ istorijskoj perspektivi jer način i ciljevi institucionalizacije govore o tome 
kakvo ponašanje može da se očekuje od regionalnih aktera. Ovde je moguće povezati perspektive "multipleks“ poretka sa praktičkim obrtom jer institucionalizacija ukazuje na to kakvi će biti obrasci „činjenja bezbednosti“ i koji su njihovi istorijski motivi. Kao razliku u odnosu na Adlera i Griv (2009), multipleks pristup ukazuje da su palete dostupnih mehanizama i praksi specifično oblikovane istorijom i idejama relevantnim u nekom regionu. „Multipleks“ perspektiva takođe može da se čita kao kritika ideje bezbednosne zajednice. Mir i saradnja u regionu mogu da nastanu i kroz očuvanje suvereniteta, ograničenu regionalnu integraciju te želju za upravljanjem i uticajem spoljnih sila u regionu. Sve to upućuje da realizam $u$ međuregionalnim bezbednosnim tokovima ne mora biti napušten i zamenjen principima zajednice.

\section{ZAKLJUČAK}

Na početku ovog pregleda postavili smo tri cilja: da predstavimo TRBK $\mathrm{u}$ savremenom proučavanju regionalne bezbednosti, da mapiramo studije regionalne bezbednosti i sagledamo odnos TRBK sa drugim (srodnim/rivalskim) teorijama, i da ocenimo karakter sagledanog odnosa TRBK i drugih teorija regionalne bezbednosti. Prema predstavljenom pregledu literature, pojava TRBK predstavljala je prekretnicu u razvoju studija regionalne bezbednosti. Iako najčešće definisani kroz prizmu funkcionalizma, regioni su do pojave TRBK prepoznati kao važne jedinice analize. Ipak, pojava teorije sekuritizacije predstavlja prekretnicu u razvoju celokupnih studija bezbednosti, što se odrazilo i na perspektivu o regionima u međunarodnoj bezbednosti. Kao ključnu inovaciju TRBK okvira uzimamo produktivno spajanje realističkih i konstruktivističkih ideja kako bi se objasnila bezbednosna dinamika regiona. Buzan i Vejver (2003) regionalnu optiku biraju jer veruju da bezbednosne pretnje lakše prelaze male razdaljine, što geografski bliske zemlje čini upućene jedne na druge. Korišćenje obrazaca međusobne sekuritizacije i desekuritizacije dalo je ovim autorima sredstvo da definišu regione. Ono što je nakon TRBK obeležilo studije bezbednosti jeste ideja da kompleksnosti savremene bezbednosne dinamike ne mogu da se razumeju bez uzimanja elemenata različitih tradicija u međunarodnim odnosima. TRBK je čak otišla i korak dalje te je pokazala da je put ka daljem razvoju regionalističkih pristupa u sintezi elemenata različitih tradicija. 
Pored TRBK uočili smo da $\mathrm{u}$ istom vremenskom periodu nastaje pristup regionalnih bezbednosnih poredaka (Lake and Morgan 1997) i da dolazi do preosmišljavanja ideje bezbednosne zajednice (Adler and Barnett 1998). Nastavljači ovih tradicija dali su značajne doprinose koji uočavaju određene nedostatke TRBK i pokušavaju da na njih adekvatno odgovore. Tako uočeni nedostaci variraju od malog broja varijabli, koji ne može da objasni varijetete dinamike regiona kod regionalnih klastera mira i bezbednosti (Tavares 2008), pa do nedefinisanih uloga i orijentacija regionalnih aktera u okviru regionalnih sila i bezbednosti (Frazier and Stewart-Ingersoll 2010). Pristupi regionalnih bezbednosnih poredaka pokazuju značajnu agilnost jer kritički dopunjuju nedostatke TRBK, iako to ne čine nužno nadograđujući teorijski okvir TRBK. Kritika koju pružaju odnosi se na eksplanatornu moć celokupnog modela TRBK. Nasuprot ovim pristupima, dalji razvoj konceptualnog aparata okvira bezbednosne zajednice nije se zasnivao na eksplicitnoj kritici TRBK, već na želji da se raniji nedostaci okvira bezbednosne zajednice koriguju kroz pozivanje na nove koncepte (poput prakse). S obzirom na to da je ideja bezbednosne zajednice od početka sastavni deo TRBK, dalje razvijanje ove ideje ostavlja otvoren prostor za komunikaciju sa TRBK. Kao jedno od mogućih mesta te komunikacije jeste pitanje fiksiranosti granica regiona. Poslednji obrađeni pristup, „multipleks“ regionalnog poretka, razvija konceptualni aparat koji naizgled slabo rezonuje sa TRBK. Ipak, celokupne pretpostavke ovakvog shvatanja regiona mogu da se čitaju kao kritika TRBK, ali i regionalnih bezbednosnih poredaka. Prostor za komunikaciju pristupa "multipleks“ regionalnog poretka i TRBK ostaje otvoren. Prema našem mišljenju, ova komunikacija mogla bi biti ostvarena kroz temeljnije proučavanje sekuritizujućeg i desekuritizujućeg rada regionalnih institucija i načina na koji preformulisanje koncepata poteklih sa Zapada utiču na specifične prakse sekuritizacije i desekuritizacije $u$ "globalnim“ međunarodnim odnosima.

Razvoj novijih pristupa $\mathrm{u}$ proučavanju regiona $\mathrm{u}$ međunarodnoj bezbednosti pokazuje da je za razumevanje kompleksnosti savremene bezbednosne dinamike potrebno nastavljati proces sinteze elemenata tradicija koji su započeli Buzan i Vejver. Sadašnje stanje teorije ukazuje da komunikacija između različitih pristupa postoji i da se kroz kritiku TRBK može doći do novih, nijansiranih i preciznih teorijskih okvira. Takođe, nije isključeno da će razvoj drugih teorija doprineti unapređivanju postojećeg okvira TRBK. Bez obzira na to što se novi pristupi razvijaju, relevantnost 
TRBK ne mora opadati jer se novi prostori komunikacije i međusobnog dopunjavanja tek otvaraju.

\section{BIBLIOGRAFIJA}

Acharya, Amitav. 2007. "The Emerging Regional Architecture of World Politics". World Politics 59 (4): 629-652.

Acharya, Amitav. 2014. The End of American World Order. Cambridge: Polity Press.

Acharya, Amitav. 2018. Constructing Global Order: Agency and Change in World Politics. Cambridge: Cambridge University Press.

Adler, Emanuel and Michael Barnett. 1998. Security Communities. Cambridge: Cambridge University Press.

Adler, Emanuel and Patricia Greve. 2009. "When Security Community Meets Balance of Power: Overlapping Regional Mechanisms of Security Governance". Review of International Studies 35 (S1): 59-84.

Ayoob, Mohammed. 1999. "From Regional System to Regional Society: Explaining Key Variables in the Construction of Regional Order". Australian Journal of International Affairs 53 (3): 247-260.

Buzan, Barry. 1991. People, States and Fear: An Agenda for International Security Studies in the Post Cold-War Era. Second Edition. Colorado: Lynne Reiner Publishers.

Buzan, Barry, Charles Jones and Richard Little. 1993. The Logic of Anarchy: Neorealism to Structural Realism. New York: Columbia University Press.

Buzan, Barry, Jaap De Wilde and Ole Waever. 1998. Security: A New Framework for Analysis. Boulder: Lynne Reiner Publishers.

Buzan, Barry and Ole Waever. 2003. Regions and Powers: The Structure of International Security. Cambridge: Cambridge University Press.

Clarke, Kevin and David Primo. 2012. A Model Discipline: Political Science and the Logic of Representation. Oxford: Oxford University Press.

Deutsch, Karl. 1954. Political Community at the International Level: Problems of Definitions and Measurement. New York: Doubleday \& Company.

Ejdus, Filip. 2012. Medunarodna bezbednost: teorije, sektori i nivoi. Beograd: Službeni glasnik i Beogradski centar za bezbednosnu politiku. 
Ejdus, Filip. 2017. Medunarodna bezbednost: teorije, sektori i nivoi. Beograd: Fakultet političkih nauka i Čigoja štampa.

Ejdus, Filip. 2018. "Professional Practices of Security Community Building: Theoretical Introduction". In: Security Community Practices in the Western Balkans, edited by Sonja Stojanović Gajić and Filip Ejdus, 1-12. New York: Routledge.

Frazier, Derrick and Robert Stewar Ingersoll. 2010. “Regional powers and security: A framework for understanding order within regional security complexes". European Journal of International Relations 16 (4): 731-753.

Hettne, Bjorn. 2005. “Beyond the 'New' Regionalism". New Political Economy 10 (4): 543-571.

Hettne, Bjorn and Fredrik Soderbaum. 2000. "Theorising the Rise of Regionness". New Political Economy 5 (3): 457-473.

Hoogensen, Gunhild. 2005. "Bottoms up! A Toast to Regional Security?". International Studies Review 7 (2): 269-274.

Hurrell, Andrew. 2007. “One world? Many worlds? The place of regions in the study of international society". International Affairs 83 (1): 127-146.

Katzenstein, Peter. 2005. A World of Regions: Asia and Europe in the American Imperium. New York: Cornell University Press.

Koschut, Simon. 2014. "Regional order and peaceful change: Security communities as a via media in international relations theory". Cooperation and Conflict 49 (4): 1-17.

Kovačević, Marko. 2013. "Regional Security in a Changing World". Journal of Regional Security 8 (2): 175-181.

Lake, David and Patrick Morgan. 1997. Regional Orders: Building Security in a New World. University Park: Pennsylvania State University Press.

Miršajmer, Džon. 2009. Tragedija politike velikih sila. Beograd: Udruženje za studije SAD u Srbiji.

Neumann, Iver. 1994. "A Region-Building Approach to Northern Europe". Review of International Studies 20 (1): 53-74.

Nojman, Iver. 2011. Upotrebe drugog: Istok u formiranju evropskog identiteta. Beograd: Beogradski centar za bezbednosnu politiku.

Nolte, Detlef. 2010. "How to compare regional powers: analytical concepts and research topics". Review of International Studies 36 (4): 881-901. 
Onuf, Nicholas. 1995. "Levels". European Journal of International Affairs 1 (1): 35-58.

Pepinsky, Thomas. 2020. "Authoritarian Innovations: Theoretical Foundations and Practical Implications". Democratization 27 (6): 10921101.

Pouliot, Vincent. 2008. "The logic of practicality: A theory of practice of security communities". International Organization 62 (2): 257-288.

Sbragia, Alberta. 2008. "Review Article: Comparative Regionalism: What Might It Be?". Journal of Common Market Studies 46 (S1): 29-49.

Sil, Rudra and Peter Katzenstein. 2010. "Analytic Eclecticism in the Study of World Politics: Reconfiguring Problems and Mechanisms across Research Traditions". Perspectives on Politics 8 (2): 411-431.

Singer, David J. 1961. "The-Level-of-Analysis Problem in International Relations". World Politics 14 (1): 77-92.

Tavares, Rodrigo. 2008. “Understanding Regional Peace and Security: A Framework for Analysis". Contemporary Politics 14 (2): 107-127.

Thompson, William. 1973. "The Regional Subsystem: A Conceptual Explication and a Propositional Inventory". International Studies Quarterly 17 (1): 89-117.

Vayrynen, Raimo. 1984. "Regional Conflict Formations: An Intractable Problem of International Relations". Journal of Peace Research 21 (4):337359.

Vayrynen, Raimo. 2003. "Regionalism: Old and New". International Studies Review 5 (1): 25-51.

Weaver, Ole. 2007. "Securitization and Desecuritization". In: International Security, edited by Barry Buzan and Lene Hansen, 66-98. London: SAGE.

Wendt, Alexander. 1999. Social Theory of International Politics. Oxford: Oxford University Press.

Wolfers, Arnold. 1962. Discord and Collaboration: Essays on International Politics. Baltimore: The Johns Hopkins Press. 


\section{REVIEWING THE CONDITION AND REACH \\ OF THE REGIONAL SECURITY COMPLEX THEORY IN THE STUDY OF REGIONS IN INTERNATIONAL RELATIONS}

Abstract: In this paper, we argue that the Regional Security Complex Theory (RSCT) (Buzan and Waever 2003) is most adequately positioned among various "regionalist" approaches in International Relations, both for theory-building and empirical research on regional security. The aims of the paper are threefold: a) to review the RSCT within contemporary International Security Studies; b) to map out regional security studies and reflect on the relationship between the RSCT and other (related/rival) theories; c) to assess the character of the relationship between the RSCT and other theories. The aforesaid aims are achieved in three steps. First, by doing a literature review, we want to point out the theoretical evolution and empirical application of the RSCT over the past two decades. Second, we offer a review and classification of relevant concepts from other "regionalist" theories which we consider to "resonate" with the RSCT framework. Third, we answer the question of whether and to what degree the RSCT is compatible with the concepts of the narrower, rival approaches. We argue the RSCT can be used as a sort of "interface" of wider regional security studies. In order to illustrate our research framework, the third part of the paper deals with and discusses the advantages that the RSCT, as a medium-range theory, has in comparison with the rival approaches that are concerned with regional orders (Katzenstein 2005; Frazier and Stewart-Ingersoll 2010), regional security communities (Adler and Barnett 1998), or regional "multiplex" order (Acharya 2014; Acharya 2018). In conclusion, the paper addresses the possibilities for hybridization between the RSCT and related/rival approaches, which have opened some important questions for further development of the research programme of regional security studies in the 2020s.

Keywords: International Relations, regionalism, regional security, Regional Security Complex Theory (RSCT), regional security order, security community, geopolitics, multipolarization. 